\title{
Effect of Laser Beam Welding Parameters on Microstructure and Properties of Duplex Stainless Steel
}

\author{
Abdel-Monem El-Batahgy ${ }^{1}$, Abdel-Fattah Khourshid ${ }^{2}$, Thoria Sharef $^{2}$ \\ ${ }^{1}$ Manufacturing Technology Department, Central Metallurgical Research and Development Institute, Cairo, Egypt; ${ }^{2}$ Mechanical De- \\ sign and Production Department, Faculty of Engineering, Tanta University, Tanta, Egypt. \\ Email: elbatahgy@yahoo.com
}

Received June 26 ${ }^{\text {th }}$, 2011; revised July $19^{\text {th }}, 2011$; accepted August $25^{\text {th }}, 2011$.

\begin{abstract}
The present study is concerned with laser beam welding and its effect on size and microstructure of fusion zone then, on mechanical and corrosion properties of duplex stainless steel welded joints. In this regard, influence of different laser welding parameters was clarified. Both bead-on-plate and autogenously butt welded joints were made using carbon dioxide laser with a maximum output of $9 \mathrm{~kW}$ in the continuous wave mode. Welded joints were subjected to visual, dye penetrant and radiography tests before sectioning it for different destructive tests. Accelerated corrosion test was carried out based on tafel plot technique. The results achieved in this investigation disclosed that welding parameters play an important role in obtaining satisfactory properties of welded joint. High laser power and/or high welding speed together with adjusting laser focused spot at specimen surface have produced welded joints with a remarkable decrease in fusion zone size and an acceptable weld profile with higher weld depth/width ratio. Besides, acceptable mechanical and corrosion properties were obtained. Using nitrogen as a shielding gas has resulted in improving mechanical and corrosion properties of welded joints in comparison with argon shielding. This is related to maintaining proper ferrite/austenite balance in both weld metal and HAZ in case of nitrogen shielding. As a conclusion, laser power, welding speed, defocusing distance and type of shielding gas combination have to be optimized for obtaining welded joints with acceptable profile as well as mechanical and corrosion properties.
\end{abstract}

Keywords: Duplex Stainless Steel, Laser Beam Welding, Laser Power, Welding Speed, Defocusing Distance, Shielding Gas Type, Fusion Zone, Microstructure, Mechanical Properties, Corrosion Resistance

\section{Introduction}

The duplex stainless steels have been developed to provide a combination of strength and resistance to pitting and stress corrosion cracking in comparison with the 300-series austenitic stainless steels [1-3]. These unique properties of the duplex stainless steels have resulted in their use in a variety of industrial applications, including chemical process plant piping, oil and gas transmission lines, and structures for use in marine environments $[4,5]$. Since welding is widely used in these applications, understanding the factors which affect the weldability of duplex stainless steels is critical to the successful implementation of these engineering materials.

Generally, the ferrite/austenite balance has a remarkable influence on both mechanical and corrosion proper- ties of duplex stainless steels [6,7]. The optimum properties of duplex stainless steels are achieved when nearly equal proportions of austenite and ferrite are present in the microstructure. In base metals, this phase balance is obtained by an appropriate combination of composition and solution heat treatment. However, control of the ferrite/austenite balance in welds is not as straightforward as in the base metals [8-11].

Previous investigations have demonstrated that microstructure of both weld and heat affected zones is a function of the cooling rate from peak temperature [12-15]. Consequently, it is expected that the ferrite/austenite balance in fusion zone is affected by laser power and welding speed. However, this research area has received comparatively little investigations and more work is required for deep understanding the effect of different laser 
welding parameters on properties of duplex stainless steels. The present study is concerned with laser beam welding and its effect on size and microstructure of fusion zone then, on mechanical and corrosion properties of duplex stainless steel welded joints.

\section{Experimental Procedure}

The used steel is a commercial duplex stainless steel; 2205 with $6.4 \mathrm{~mm}$ plate thickness. Its chemical composition and mechanical properties are given in Table $\mathbf{1}$. Both bead-on-plate and autogenously single pass square butt welds were made using $\mathrm{CO}_{2}$ laser beam welding process. Schematic illustration of laser butt welding joint is shown in Figure 1. Weld specimens $(150 \times 100 \times 6.4$ $\mathrm{mm}$ ) were prepared as square butt joints with machined surfaces and were held firmly using fixture to prevent distortion. Laser beam welding parameters studied are given in Table 2.

The used laser was a carbon dioxide with a maximum output power of $9 \mathrm{~kW}$ in the continuous wave mode. After welding, the specimens were visually inspected, radiographed then, sectioned transverse to the welding direction where it were subjected to metallographic examinations as well as mechanical and corrosion tests. For metallographic examination, the specimens were prepared using standard techniques. The size and microstructure of fusion zone were examined using optical microscope. Compositional variations across welded joints were determined in scanning electron microscope equipped with an energy dispersive spectrometer (EDS) at an accelerating voltage of $30 \mathrm{kV}$. The elements ana- lyzed included both ferrite and austenite stabilizing elements.

Mechanical tests including tensile, bending and hardness were performed for laser beam butt welded joints having complete penetration. These tests were performed at room temperature according to relevant standards. Tensile test was performed for three samples in each condition and the data reported are the average of the three individual results. The given hardness values are the average of five readings. Regarding corrosion test, selected laser beam welded samples were subjected to accelerated corrosion test based on tafel plot technique where corrosion rate was measured using Potentiostat-Auto Lab PGSTAT 30 device.

\section{Results and Discussion}

\subsection{Effect of Laser Power}

The effect of laser power was clarified using $0.5 \mathrm{~m} / \mathrm{min}$ welding speed, 0.0 and $-2.0 \mathrm{~mm}$ defocusing distances. Figure 2 shows macrographs of cross sections of laser bead-on-plate welds made using $0.5 \mathrm{~m} / \mathrm{min}$ welding

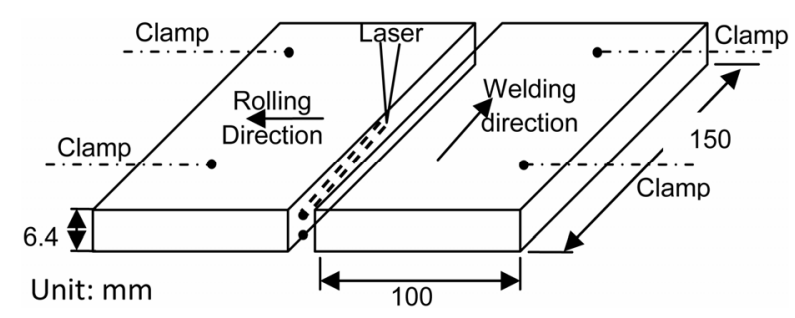

Figure 1. Schematic illustration of laser butt welding joint.

Table 1. Chemical composition (wt \%) and mechanical properties of used base metal.

\begin{tabular}{|c|c|c|c|c|c|c|c|c|c|}
\hline \multicolumn{10}{|c|}{ Chemical composition } \\
\hline $\mathrm{Cr}$ & $\mathrm{Ni}$ & $\mathrm{Mn}$ & $\mathrm{C}$ & $\mathrm{Si}$ & $P$ & $\mathrm{~S}$ & Mo & $\mathrm{Cu}$ & $\mathrm{N}$ \\
\hline 21.9 & 4.70 & 1.71 & 0.03 & 0.50 & 0.03 & 0.002 & 2.60 & 0.20 & 0.17 \\
\hline \multicolumn{10}{|c|}{ Mechanical properties } \\
\hline \multicolumn{3}{|c|}{ Tensile strength (MPa) } & \multicolumn{4}{|c|}{ Yield strength (MPa) } & \multicolumn{3}{|c|}{ Elongation (\%) } \\
\hline \multicolumn{3}{|c|}{730} & \multicolumn{3}{|c|}{685} & & \multicolumn{3}{|c|}{30} \\
\hline
\end{tabular}

Table 2. Laser beam welding parameters.

\begin{tabular}{ccccc}
\hline Weld type & $\mathrm{P}(\mathrm{kW})$ & $\mathrm{S}(\mathrm{m} / \mathrm{min})$ & $\Delta \mathrm{Z}(\mathrm{mm})$ & Shielding gas/ Flow rate $(\mathrm{l} / \mathrm{min})$ \\
\hline Bead-on-plate & $4,5,6,7,7.5,8$ & 0.5 & $-2,0$ & Argon $/ 20$ \\
Bead-on-plate & 7 & $0.25,0.4,0.5,1,2,3,4,5,6$ & $-2,0$ & Argon $/ 20$ \\
Bead-on-plate & 7 & 0.5 & $3,2,1,0,-1,-2,-3,-4$ & Argon $/ 20$ \\
Butt joint & 8 & $0.25,0.5$ & -2 & Nitrogen $/ 20$ \\
\hline
\end{tabular}

P: Power; S: Speed; $\triangle \mathrm{Z}$ : Defocusing distance. 

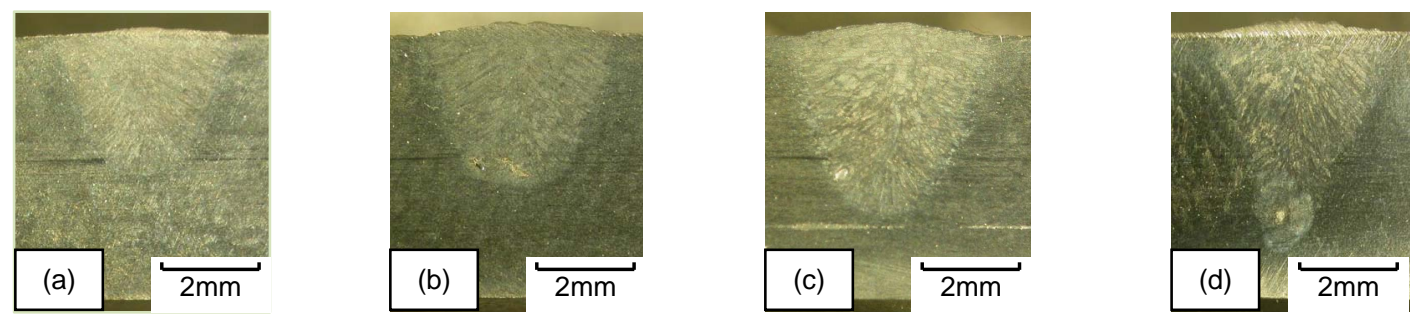

Figure 2. Macrographs of cross sections of laser bead-on-plate welds made using $0.5 \mathrm{~m} / \mathrm{min}$ speed, $-2 \mathrm{~mm}$ defocusing distance, $20 \mathrm{l} / \mathrm{min} \mathrm{Ar}$ and different laser powers. (a) $4 \mathrm{~kW}$; (b) $5 \mathrm{~kW}$; (c) $7 \mathrm{~kW}$; (d) $8 \mathrm{~kW}$.

speed, $-2 \mathrm{~mm}$ defocusing distance, $201 / \mathrm{min} \mathrm{Ar}$ and different laser powers. It is clear that penetration depth increases with increasing laser power. The weld bead showed a characteristic of laser welding where the development of the weld is essentially symmetrical about the axis of the laser beam. No welding cracks or porosity were found and this could be partly due to the good crack resistance of the base metal and the welding conditions provided. Figure 3 summarizes the results of penetration depth measurements as a function of laser power. It can be noticed that penetration depth is sharply increasing with the increase of laser power. It increased from $3.4 \mathrm{~mm}$ to $4.7 \mathrm{~mm}$ with increasing power from 4 to $8 \mathrm{~kW}$.

\subsection{Effect of Laser Welding Speed}

Macrographs of cross sections of laser bead-on-plate welds made using $8 \mathrm{~kW}$ laser power, $-2 \mathrm{~mm}$ defocusing distance, $20 \mathrm{l} / \mathrm{min} \mathrm{Ar}$ and different welding speeds are shown in Figure 4. It is noteworthy that the fusion zone is symmetrical about the axis of the laser beam. However, size and depth/width ratio of fusion zone are significantly affected by welding speed. A lower welding speed resulted in a remarkable increase in the fusion zone size. Also, weld depth/width ratio was remarkably increased with decreasing welding speed. Consequently, acceptable weld profile was obtained where the fusion zone interface is a smooth curve with no inflections. Complete penetration with relatively acceptable fusion zone size for the $6.4 \mathrm{~mm}$ base metal thickness was obtained at welding speed of $0.25 \mathrm{~m} / \mathrm{min}$ (Figure 4(d)). In other words, $0.25 \mathrm{~m} / \mathrm{min}$ is considered as the optimum welding speed at $8 \mathrm{~kW}$ laser power since it resulted in fusion zone with a slight taper configuration. This fusion zone shows a characteristic of laser welding with an acceptable weld depth/width ratio. At low welding speed, attenuation of beam energy by plasma is less significant. This results in relatively more exposure of the laser beam on the sample surface. Consequently, the depth/width ratio would be decreased and the fusion zone would be increased.

Inspite of the development of the weld is essentially symmetrical about the axis of the laser beam, increase

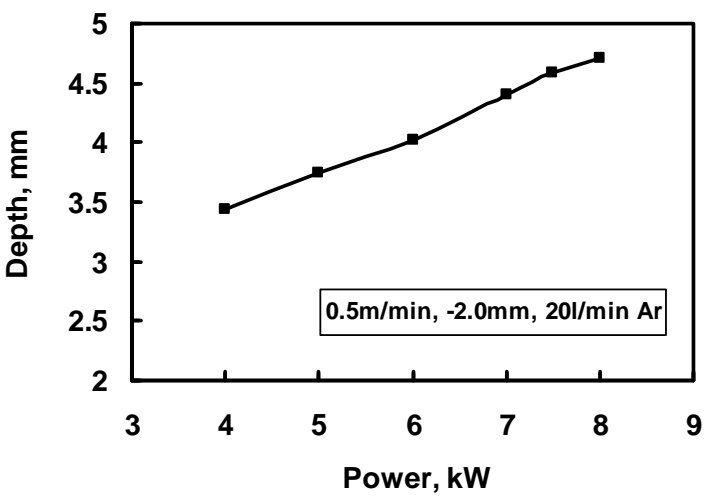

Figure 3. Effect of laser power on weld depth of laser beadon-plate welds made using $0.5 \mathrm{~m} / \mathrm{min}$ speed and $-2 \mathrm{~mm}$ defocusing distance and $20 \mathrm{l} / \mathrm{min}$ Ar shielding.

penetration at the root side was observed particularly at lower welding speed suggesting an unsteady fluid flow. This is due to the presence of two strong and opposing forces, namely, the electromagnetic and the surface tension gradient forces. At these locations, the electromagnetic force may have overcome the surface tension force, thereby, influencing convective heat transfer. As a result, any local perturbation in the over weld can cause the flow field to change dramatically, resulting in the observed increased penetration.

It can be noticed that no welding cracks or porosity were found and this could be partly due to the good crack resistance of base metal and the welding conditions provided. Figure 5 summarizes the results of weld depth measurements as a function of welding speed. Weld depth is decreased with the increase in welding speed. It decreased from $7.4 \mathrm{~mm}$ to $1.9 \mathrm{~mm}$ with increasing welding speed from 0.25 to $6 \mathrm{~m} / \mathrm{min}$.

\subsection{Effect of Defocusing Distance}

Defocusing distance, focus position, is the distance between specimen surface and optical focal point. In order to study its effect on both penetration depth and weld profile, bead-on-plate was made with changing defocusing distance of $-4.0 \mathrm{~mm}$ up to $3.0 \mathrm{~mm}$. Welding conditions were selected to obtain incomplete penetration. 

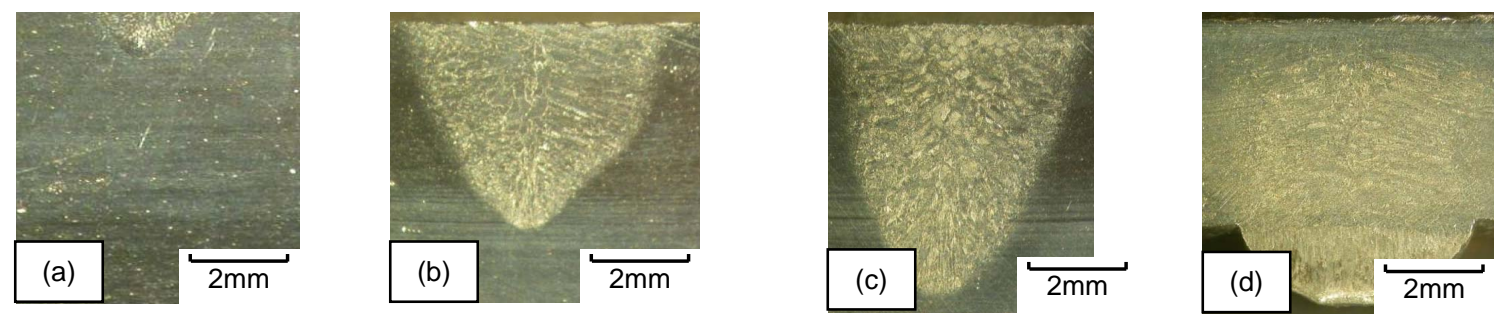

Figure 4. Macrographs of cross sections of laser bead-on-plate welds made using $8 \mathrm{~kW}$ laser power, $-2 \mathrm{~mm}$ defocusing distance, $20 \mathrm{l} / \mathrm{min}$ Ar and different welding speeds. (a) $5 \mathrm{~m} / \mathrm{min}$; (b) $1 \mathrm{~m} / \mathrm{min}$; (c) $0.5 \mathrm{~m} / \mathrm{min}$; (d) $0.25 \mathrm{~m} / \mathrm{min}$.

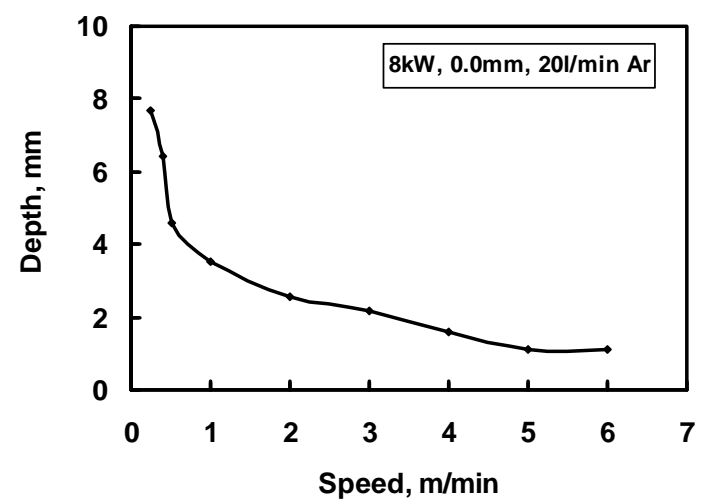

Figure 5. Effect of welding speed on weld depth of laser bead-on-plate welds made using $8 \mathrm{~kW}$ power, $-2 \mathrm{~mm}$ defocusing distance and $20 \mathrm{l} / \mathrm{min}$ Ar shielding.

Examples of macrographs of cross sections of laser bead-on-plate welds made using $8 \mathrm{~kW}$ power, $0.5 \mathrm{~m} / \mathrm{min}$ welding speed, $20 \mathrm{l} / \mathrm{min}$ argon shielding and different defocusing distances are shown in Figure 6. No cracking or porosity was observed in all welds. Figure 7 summarizes results of weld bead depth/width ratio as a function of defocused distance of laser bead-on-plate welds made using $8 \mathrm{~kW}$ power, $0.5 \mathrm{~m} / \mathrm{min}$ welding speed and $20 \mathrm{l} / \mathrm{min}$ Ar. Changing defocusing distance from zero to either minus or plus values has resulted in decrease in depth/ width ratio. In other words, shifting the focused beam position to either below or above specimen surface results in decrease in depth/width ratio. However, shifting the focused beam position above the specimen surface results in much decrease in depth/width ratio in comparison with shifting it below specimen surface. This is related to decrease in laser beam density in case of shifting the focused beam position above specimen surface. The above results are in good agreement with other research work [16].

\subsection{Effect of Type of Shielding Gas}

Based on results obtained from above experiments, optimum welding parameters were obtained and implemented for welding square butt joints. Nondestructive investigations including visual, dye penetrant and radio- graphic tests confirmed that laser butt welded joint is free from both external and internal defects. Then, welded joint was sectioned for metallographic examinations. Figure 8(a) shows macrograph of a cross section of laser butt welded joints made using $8 \mathrm{~kW}$ power, $0.5 \mathrm{~m} / \mathrm{min}$ speed, $0.0 \mathrm{~mm}$ defocusing distance and $20 \mathrm{l} / \mathrm{min}$ argon. Fusion zone shows a characteristic of laser welding with complete penetration and acceptable weld profile where the fusion zone interface is a smooth curve with no inflections.

In order to clarify the effect of shielding gas type, argon was replaced by nitrogen with other welding conditions kept constant. Figure 8(b) shows macrograph of a cross section of laser butt welded joint made using $8 \mathrm{~kW}$ power, $0.5 \mathrm{~m} / \mathrm{min}$ speed, $0.0 \mathrm{~mm}$ defocusing distance and $20 \mathrm{l} / \mathrm{min}$ nitrogen. It can be noticed that typical laser weld with complete penetration and acceptable weld profile, similar to that of argon shielding, was obtained.

\subsection{Microstructure of Laser Butt Welds}

The microstructure of the used 2205 duplex stainless steel base metal is shown in Figure 9. It can be noticed that this microstructure is duplex with approximately equal volumes of both ferrite and austenite phases. Since hot working of duplex stainless steel is normally performed in the austenite-ferrite, two phase region, the resultant microstructure tends to be strongly oriented along the working direction. An average hardness value of about $305 \mathrm{Hv}$ was obtained for this microstructure.

Optical micrographs of laser butt welded joint made using $8 \mathrm{~kW}$ power, $0.5 \mathrm{~m} / \mathrm{min}$ speed, $0.0 \mathrm{~mm}$ defocusing distance and $20 \mathrm{l} / \mathrm{min}$ of argon and nitrogen shielding are shown in Figures 10 and $\mathbf{1 1}$ respectively. The noticeable feature is the highly directional nature of the microstructure around the axis of the laser beam in both cases. This is due to solidification of the weld metal at high cooling rate. No solidification cracking was found in the weld structure. Structures of weld metal in both joints were almost similar. For weld metal, a dendritic microstructure was developed at fusion boundary due to fast cooling conditions (Figures 10(c), 11(c)). More globular structures were observed at weld metal center that exposed to 

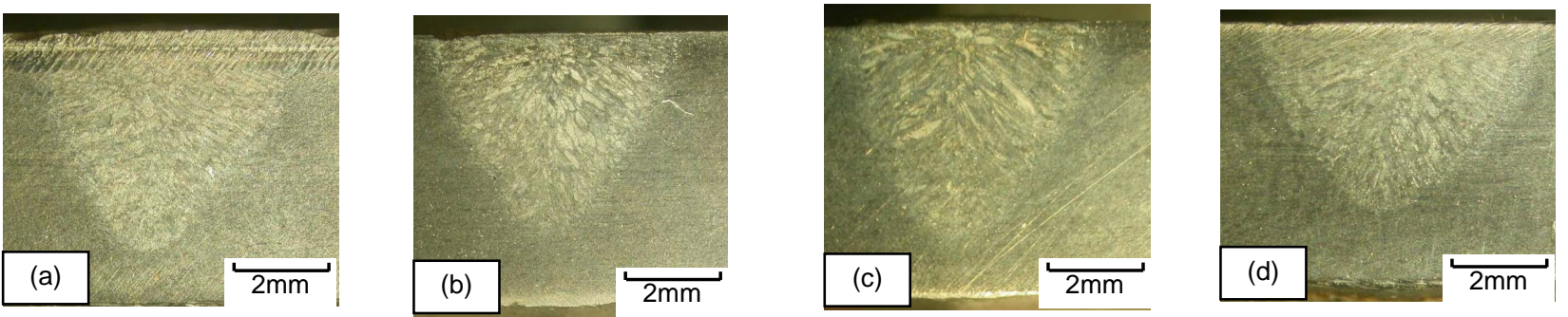

Figure 6. Macrographs of cross sections of laser bead-on-plate welds made using $8 \mathrm{~kW}$ power, $0.5 \mathrm{~m} / \mathrm{min}$ speed, 20 l/min Ar with difference defocusing distances. (a) $\mathrm{Dd}=-4 \mathrm{~mm}$; (b) $\mathrm{Dd}=-1 \mathrm{~mm}$; (c) $\mathrm{Dd}=0.0 \mathrm{~mm}$; (d) $\mathrm{Dd}=+3 \mathrm{~mm}$.

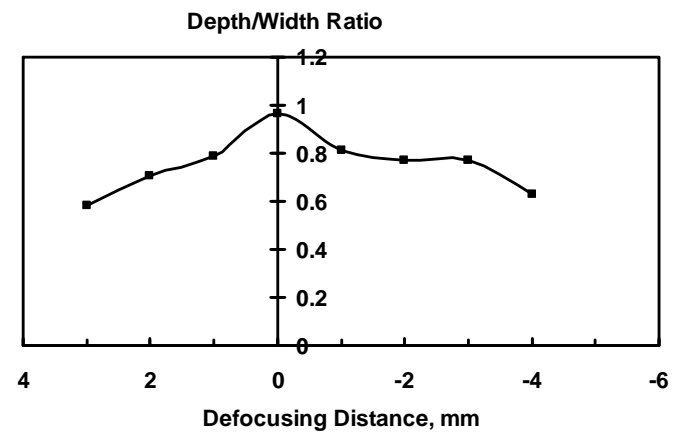

Figure 7. Weld bead depth/width ratio versus defocusing distance of laser bead-on-plate welds made using $8 \mathrm{~kW}$ power, $0.5 \mathrm{~m} / \mathrm{min}$ speed and $20 \mathrm{l} / \mathrm{min} \mathrm{Ar}$.
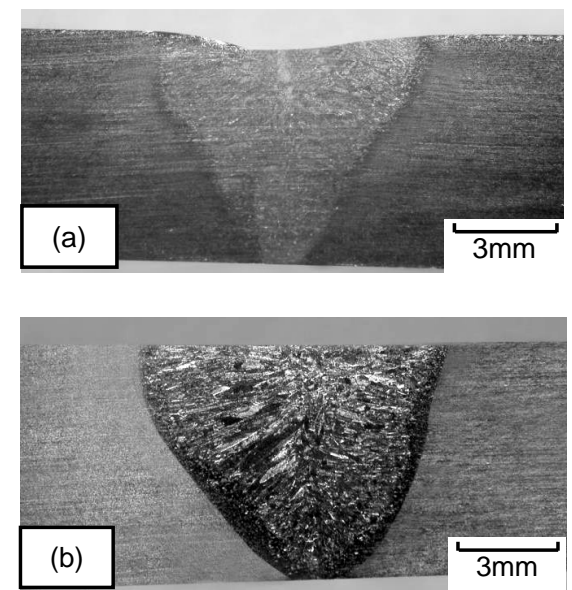

Figure 8. Macrographs of cross sections of laser butt welded joints made using $8 \mathrm{~kW}$ power, $0.5 \mathrm{~m} / \mathrm{min}$ speed, $0.0 \mathrm{~mm}$ defocusing distance and $20 \mathrm{l} / \mathrm{min}$ of (a) argon; (b) nitrogen.

lower cooling rates and with a less pronounced heat flow direction. During solidification of duplex weld metal an almost completely ferrite structure is formed. Further cooling initiates the formation of the austenite phase nucleating at the ferrite grain boundaries. In other words, duplex stainless steel weld metal solidifies completely to $\alpha$-ferrite and the volume fraction of austenite is determined by subsequent solid state phase transformation (17).

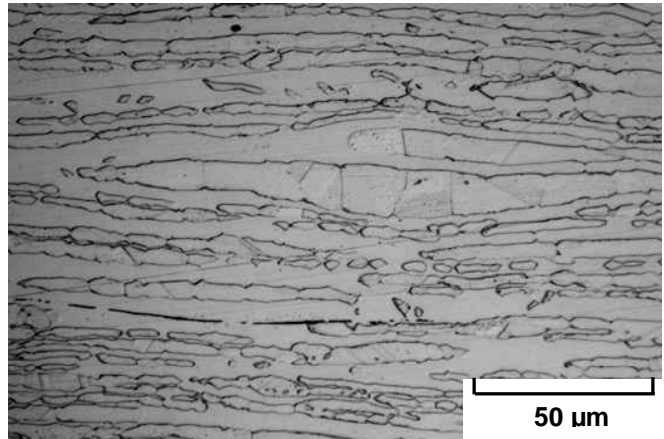

Figure 9. Optical micrographs of base metal of duplex stainless steel used.

Regarding heat affected zone, its microstructure is critical for welded joint properties. In general, narrow HAZ of about $400-500 \mu \mathrm{m}$ was observed for the examined welds (Figures 10(a), 11(a)). The heat affected zone is consisting firstly of a grain growth zone characterized by coarse $\alpha$-ferrite grains decorated with allotriomorphic layers of austenite, some austenite plates and some intra-granularly nucleated particles formed on inclusions where the volume fraction of austenite in this region is low compared with the base metal. Beyond this partially ferritised zone, the major difference being the spacing of the grains which is a function of the distance from the fusion zone and the peak temperature reached during heating. In other words, the coarse grained region adjacent to the fusion line could be resulted from nearly complete austenite dissolution on heating and subsequent ferrite grain growth. Higher magnifications for HAZ microstructure are shown in color etching in Figure 12 and hardness measurements allowed a clear distinction between the ferrite and austenite in both weld metal and HAZ. The ferrite content in both weld metal and HAZ was relatively higher in comparison to base metal. This has been confirmed using energy dispersive X-ray (EDX) technique. Results showed that the concentrations of elements; such as $\mathrm{Cr}$ and $\mathrm{Mn}$ in ferrite phase is higher, while Ni concentration is lower than in austenitic phase. The element partitioning between ferritic and austenitic phase is consistent with the stabilizing effect of each 

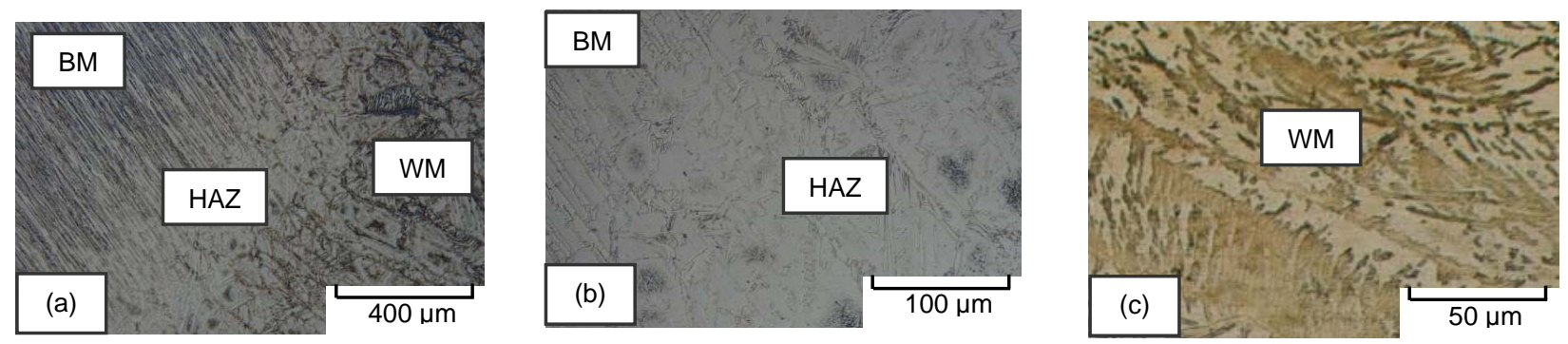

Figure 10. Optical micrographs of laser butt welded joint made using $8 \mathrm{~kW}$ power, $0.5 \mathrm{~m} / \mathrm{min}$ speed, $0.0 \mathrm{~mm}$ defocusing distance and $20 \mathrm{l} / \mathrm{min}$ argon shielding.
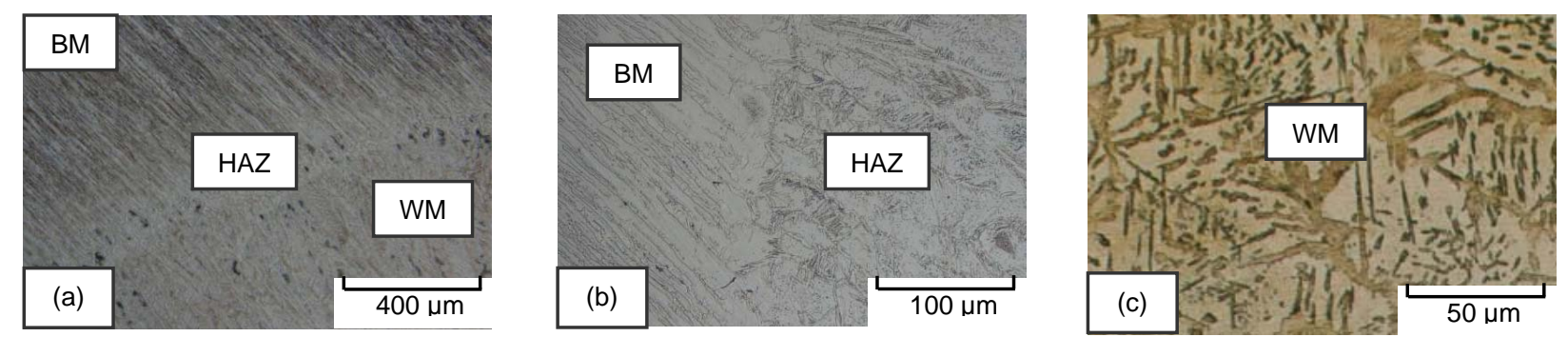

Figure 11. Optical micrographs of laser butt welded joint made using $8 \mathrm{~kW}$ power, $0.5 \mathrm{~m} / \mathrm{min}$ speed, $0.0 \mathrm{~mm}$ defocusing distance and $20 \mathrm{l} / \mathrm{min}$ nitrogen shielding.
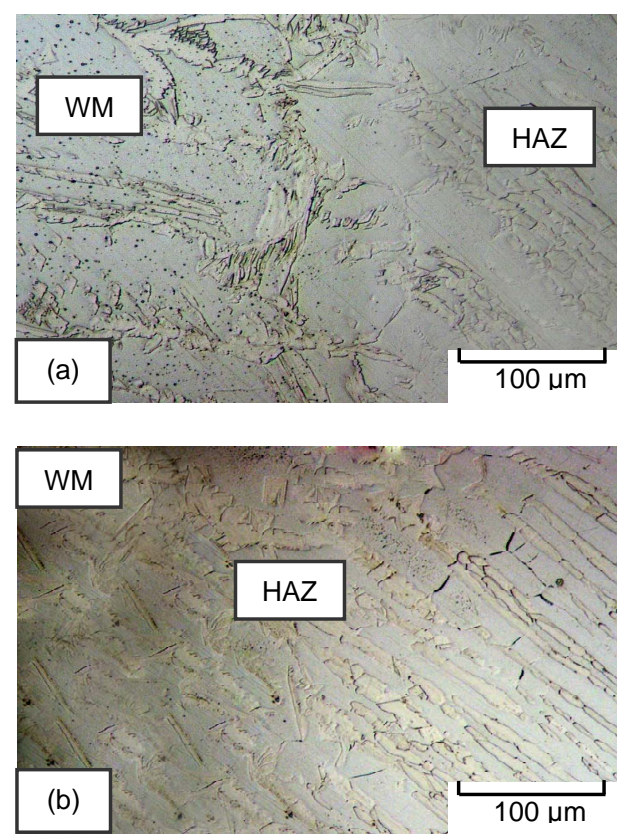

Figure 12. Color etched optical micrographs of HAZ of laser butt welded joint made using $8 \mathrm{~kW}$ power, $0.5 \mathrm{~m} / \mathrm{min}$ speed, $0.0 \mathrm{~mm}$ defocusing distance and $20 \mathrm{l} / \mathrm{min}$ of (a) argon shielding; (b) nitrogen shielding.

element on the respective phase.

Generally, laser weld results in a rapid cooling rate through the transformation temperature range which in turn resulted in decreasing austenite content and this agreed qualitatively with optical metallography. Variation in ferrite/austenite balance among different heat input of laser welds can be rationalized using a constant iron section of a Fe-Cr-Ni ternary phase diagram. The composition band superimposed on the $60 \%$ constant iron section is representative of the range of duplex stainless steel considered in this investigation. The diagram predicts that primary solidification of this alloy occurs as delta ferrite and that the structure is completely ferritic at completion of solidification. On cooling in the solid state, partial transformation of ferrite to austenite occurs at temperatures below the ferrite solves. The austenite content formed during cooling in solid state is depended on cooling rate. The higher the laser power and/or the lower welding speed, the coarser is the dendritic structure due to decreasing cooling rate. However, the effect of laser power was relatively less than that of welding speed.

\subsection{Mechanical Properties of Laser Butt Welds}

Hardness profile through weld metal, HAZ and base metal of welded joint made using $8 \mathrm{~kW}$ power, 0.5 $\mathrm{m} / \mathrm{min}$ speed, $0.0 \mathrm{~mm}$ defocusing distance and $20 \mathrm{l} / \mathrm{min}$ argon is shown in Figure 13. It can be noticed that no significant difference in hardness values of weld metal, HAZ and base metal was obtained. Similar hardness profile was obtained in case of nitrogen shielding.

The bending test at room temperature showed good ductility for all joints where no cracks were found after U-bends made. Results of tensile test of laser butt welded joint, made using $8 \mathrm{~kW}$ power, $0.5 \mathrm{~m} / \mathrm{min}$ speed, $0.0 \mathrm{~mm}$ 


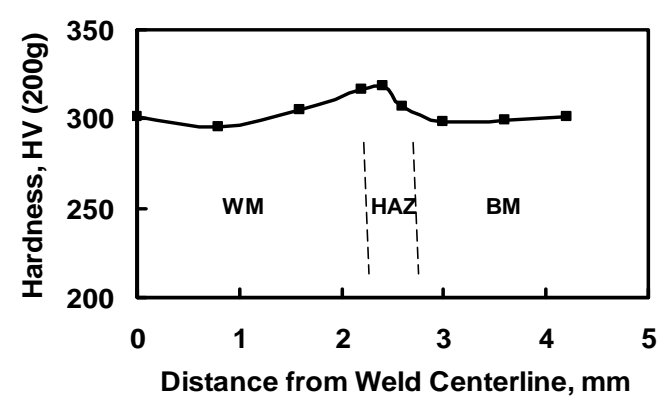

Figure 13. Hardness profile through weld metal, HAZ and base metal of welded joint made using $8 \mathrm{~kW}$ power, 0.5 $\mathrm{m} / \mathrm{min}$ speed, $0.0 \mathrm{~mm}$ defocusing distance and $20 \mathrm{l} / \mathrm{min}$ argon.

defocusing distance and $20 \mathrm{l} / \mathrm{min}$ argon, as well as that of base metal are shown in Table 3 . Tensile tested welded specimens were failed outside weld zone. Tensile properties of welded specimens are very close to that of base metal. Only, ductility or elongation of welded joint is slightly lower than that of base metal. This is related to decreasing austenite volume fraction of welded joint in comparison with base metal.

The obtained mechanical properties, in general, are correlated to microstructure that was affected by shielding gas type. In other words, mechanical properties of welds made using nitrogen shielding are relatively improved in comparison with that of welds made using argon shielding. This could be related to better balancing of ferrite-austenite phases in both weld metal and heat affected zone since nitrogen is austenite stabilizer and is of great importance in the reforming of austenite that in turn could result in structure with approximately equal amounts of ferrite and austenite, similar to that of base metal. This is conformed to results of other researchers' work [18].

It should be reported that tensile elongation of laser welded joint was not remarkably affected by increasing heat input as a function of higher laser power and/or lower welding speed inspite of higher austenite volume fraction in this case. This could be related to larger fusion zone size in case of higher heat input. In other words, the effect of fusion zone size to decrease tensile elongation is higher than the effect of austenite volume fraction to increase it.
Table 3. Tensile properties of laser butt welded joint made using $8 \mathrm{~kW}$ power, $0.5 \mathrm{~m} / \mathrm{min}$ speed, $0.0 \mathrm{~mm}$ defocusing distance and $20 \mathrm{l} / \mathrm{min}$ argon, as well as that of base metal.

\begin{tabular}{cccc}
\hline $\begin{array}{c}\text { Tensile } \\
\text { specimen }\end{array}$ & $\begin{array}{c}\text { Tensile strength } \\
(\mathrm{MPa})\end{array}$ & $\begin{array}{c}\text { Yield strength } \\
(\mathrm{MPa})\end{array}$ & $\begin{array}{c}\text { Elongation } \\
(\%)\end{array}$ \\
\hline Welded joint & 713 & 669 & 25 \\
Base metal & 730 & 685 & 30 \\
\hline
\end{tabular}

\subsection{Corrosion Properties of Laser Butt Welds}

The effect of both heat input, as a function of welding speed, and shielding gas type on corrosion resistance of laser butt welded joints are shown in Table 4 and Figure 14. It is found that corrosion rate of welded joint decreases with the increase in welding speed that means with the decrease in heat input. This effect of heat input can be rationalized in terms of cooling rate. For the low heat input of laser welds, the fast cooling rate resulted in insufficient amount of austenite and significant chromium nitride precipitation. This could lead to depletion of chromium around these precipitates which in turn could have a deleterious effect on the pitting resistance. It is found also that using nitrogen as a shielding gas to replace argon, under same flow condition, has resulted in a remarkable decrease in corrosion rate of welded joint (Figure 14). Again, improvement in corrosion properties of laser beam welded joints made using nitrogen as a shielding gas is related to improvement in ferrite-austenite balance in both weld metal and heat affected zone, as has been reported by other research works [19,20].

\section{Conclusions}

Based on the results achieved in this study, it can be concluded that laser power, welding speed, defocusing distance and type of shielding gas combinations have to be optimized for obtaining welded joints with acceptable fusion zone size, weld profile as well as mechanical and corrosion properties.

The minimum fusion zone produced by laser beam is depended on heat input as a function of laser power and welding speed. High laser power and high welding speed together with adjusting laser focused spot at specimen surface have produced welded joint with a remarkable decrease in fusion zone size and an acceptable weld profile

Table 4. Corrosion rate of laser beam welded joints made using different welding speeds and different shielding gases.

\begin{tabular}{ccc}
\hline Welding condition & Corrosion rate, mm/year & Remarks \\
\hline $8 \mathrm{~kW}, 0.5 \mathrm{~m} / \mathrm{min}, 20 \mathrm{l} / \mathrm{min}$, Nitrogen & 0.001637 & Weld metal-fusion line corrosion \\
$8 \mathrm{~kW}, 0.5 \mathrm{~m} / \mathrm{min}, 20 \mathrm{l} / \mathrm{min}$ Argon & 0.05334 & Weld metal-fusion line corrosion \\
$8 \mathrm{~kW}, 0.25 \mathrm{~m} / \mathrm{min}, 20 \mathrm{l} / \mathrm{min}$, Argon & 0.2171 & Weld metal-fusion line corrosion \\
\hline
\end{tabular}




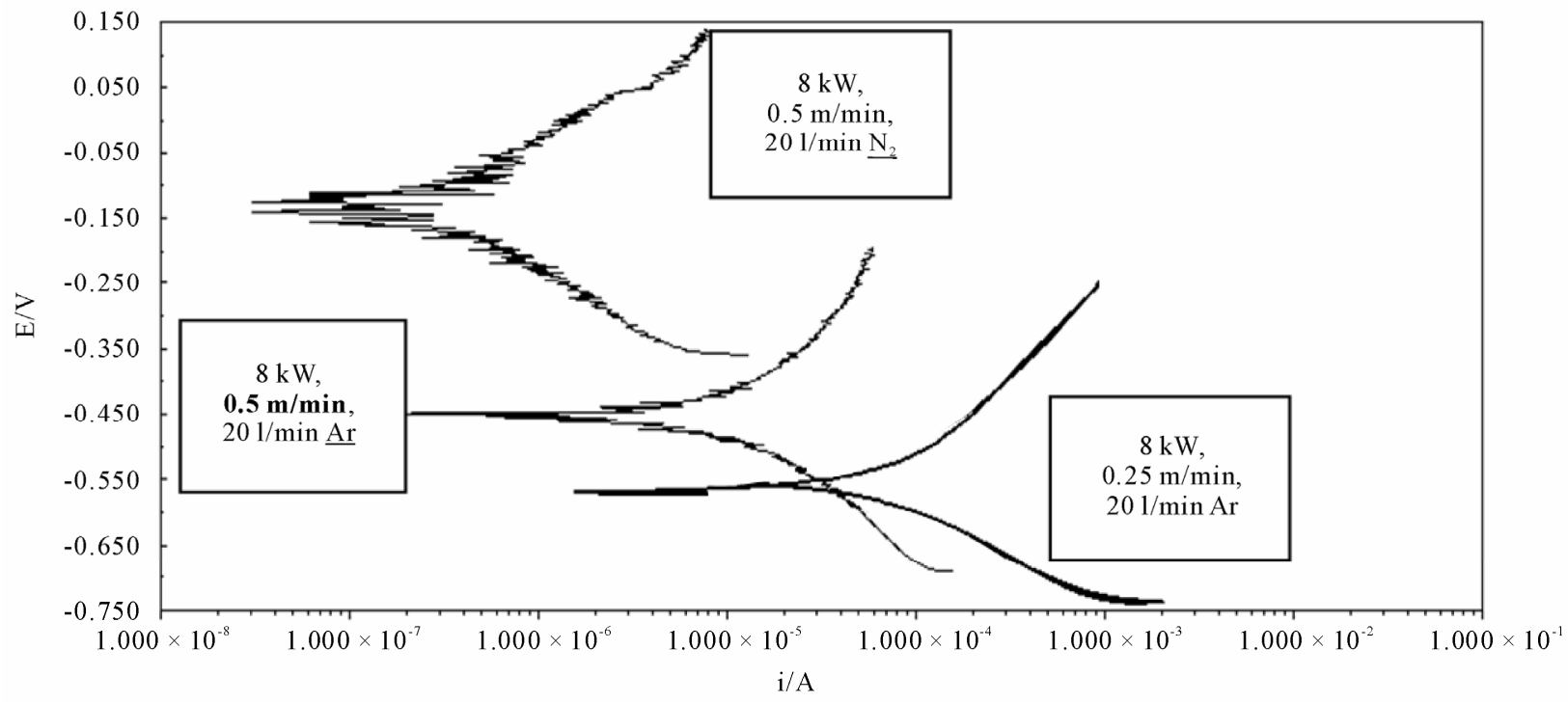

Figure 14. Comparison between corrosion rate of laser beam welded joints made using different welding speeds and shielding gases.

with higher weld depth/width ratio. The nature of ferrite to austenite transformation in fusion zone is strongly influenced by cooling rate, which is depended on heat input as a function of laser power and/or welding speed. Low heat input laser welds resulted in considerable variation in the ferrite/austenite balance of fusion zone relative to the base metal as a result of high cooling rate.

Satisfactory mechanical properties including yield strength, tensile strength, elongation and bending were obtained for laser welds. Results indicated that heat input has no remarkable effect on mechanical properties, except elongation that was improved with either increasing laser power or decreasing welding speed that means with increasing heat input. This is related to maintaining proper ferrite-austenite balance in fusion zone in this case. Using nitrogen to replace argon as a shielding gas, under same flow rate, has resulted in remarkable decrease in corrosion rate and increase in ductility of welded joint. Improvement in both mechanical and corrosion properties of laser beam welded joints made using nitrogen as a shielding gas is related to maintaining proper ferriteaustenite balance in both weld metal and heat affected zone.

\section{Acknowledgements}

The authors would like to acknowledge Libyan Research Institute for conducting laser beam welding experiments.

\section{REFERENCES}

[1] B. I. Voronenko, "Austenitic-Ferritic Stainless Steels: A State-of-the Art Review," Metal Science and Heat Treatment, Vol. 39, No. 9-10, 1997, pp. 428-437.

\section{doi:10.1007/BF02484228}

[2] A. Poznansky, C. S. Nalbone and J. D. Crawford, "The Corrosion Resistance of 25Cr-3.5Mo-6Ni and 25Cr 4.5Mo6Ni Cast Duplex Stainless Steels," Proceedings of International Conference, Duplex Stainless Steels, St. Louis, 25-28 October 1983, pp. 431-444.

[3] N. Lopez, M. Cid and M. Puigalli, "Influence of $\sigma$-Phase on Mechanical Properties and Corrosion Resistance of Duplex Steels," Corrosion Science, Vol. 41, No. 8, 1999, pp. 1615-1631. doi:10.1016/S0010-938X(99)00009-8

[4] M. Tynell, "Applicability Range for a High Strength Duplex Stainless Steel in Deep Sour Oil and Gas Wells," Proceedings of International Conference, Duplex Stainless Steels, St. Louis, 25-28 October 1983, pp. 283-292.

[5] H. Miyuki, T. Kudo, M. Koso, M. Miura and T. Moroishi, " $25 \%$ Cr Containing Duplex Phase Stainless Steel for Hot Sea Water Applications," Proceedings of International Conference, Duplex Stainless Steels, St. Louis, 25-28 October 1983, pp. 95-112.

[6] S. M. Tavares, V. F. Terra, J. M. Pardal and M. P. Fonseca, "Influence of the Microstructure on the Toughness of a Duplex Stainless Steel UNS S31803," Journal of Materials Science, Vol. 40, No. 1, 2005, pp. 145-154. doi:10.1007/s10853-005-5700-7

[7] L. F. Svensson and B. Gretoft, "Properties-Microstructure Relationship for Duplex Stainless Steel Weld Metals," Proceedings of International Conference, Duplex Stainless Steel, The Hague, 27-28 October 1986, Paper 22.

[8] M. Miura, T. Kudo, M. Tsuge, M. Kuso and T. Kobayashi, "Effect of Chemical Composition on Microstructure, Mechanical and Corrosion Properties of Duplex Stainless Steel Weldment," Proceedings of International Conference, Duplex Stainless Steel, The Hague, 27-28 October 1986, paper 33C.

[9] J. Dobranszky and J. Ginsztler, "Microstructural Stability 
of Duplex Stainless Steel Weldments," Materials Science Forum, Vol. 561-565, 2007, pp. 2119-2122. doi:10.4028/www.scientific.net/MSF.561-565.2119

[10] V. Muthupandi, P. B. Srinivasan, S. K. Seshadri and S. Sundaresan, "Effect of Weld Metal Chemistry and Heat Input on the Structure and Properties of Duplex Stainless Steels," Materials Science Engineering: A, Vol. 358, No. 1-2, 2003, pp. 9-16. doi:10.1016/S0921-5093(03)00077-7

[11] J. Honeycombe and T. G. Gooch, "Intergranular Attack in Welded Stress-Corrosion Resistant Stainless Steels," Welding Journal, Vol. 56, No. 11, 1977, pp. 339-s-353-s.

[12] R. Mundt and H. Hoffmeister, "Effect of Chemical Composition and Weld Thermal Cycles on Phase Transformation and Microstructures of Ferrite-Austenite Steels," Proceedings of International Conference, Stainless Steel, Gothenberg, 3-4 September 1984, pp. 315-322.

[13] S. Jana, "Effect of Heat Input on HAZ Properties of Two Duplex Stainless Steels," Journal of Materials Processing Technology, Vol. 33, No. 3, 1992, pp. 247-261. doi:10.1016/0924-0136(92)90211-A

[14] B. Bonnefois, R. Blondeau and D. Catelin, "Control of the Ferrite Level in Duplex Stainless Steel Welds," Proceedings of International Conference, Duplex Stainless Steel, The Hague, 27-28 October 1986, Paper 6.

[15] J. Ku, N. Ho and S. Tjong, "Properties of Electron Beam Welded SAF 2205 Duplex Stainless Steel," Journal of Materials Processing Technology, Vol. 63, No. 1-3, 1993, pp. 770-775. doi:10.1016/S0924-0136(96)02721-5

[16] A. El-Batahgy, "Effect of Laser Beam Welding Parameters on Fusion Zone Shape and Microstructure of Austenitic Stainless Steel," Materials Letters, Vol. 32, No. 2-3, 1997, pp. 155-163. doi:10.1016/S0167-577X(97)00023-2

[17] J. Nowacki and A. Lukojc, "Microstructural Transformations of Heat Affected Zones in Duplex Steel Welded Joints," Materials Characterization, Vol. 56, No. 4-5, 2006, pp. 436-441. doi:10.1016/j.matchar.2006.02.007

[18] T. Omura, T. Kushida and Y. Komizo, "Effect of Nitrogen Distribution on Rapid Solidification in Laser Welded Duplex Stainless Steels," Welding International, Vol. 14, No. 4, 2000, pp. 288-294. doi:10.1080/09507110009549181

[19] P. Bala Srinivasan, V. Muthupandi, W. Dietzel and V. Sivan, "Microstructure and Corrosion Behavior of Shielded Metal Arc Welded Dissimilar Joints Comprising Duplex Stainless Steel and Low Alloy Steel," Materials Engineering and Performance, Vol. 15, No. 6, 2006, p. 758. doi:10.1361/105994906X150902

[20] G. Lothongkum, P. Wongpanya, S. Morito, T. Furuhara and T. Maki, "Effect of Nitrogen on Corrosion Behaviour of 28Cr-7Ni Duplex and Microduplex Stainless Steels in Air-Saturated $3.5 \mathrm{wt} \% \mathrm{NaCl}$ Solution," Corrosion Science, Vol. 48, No. 1, 2006, pp. 137-153. doi:10.1016/j.corsci.2004.11.017 